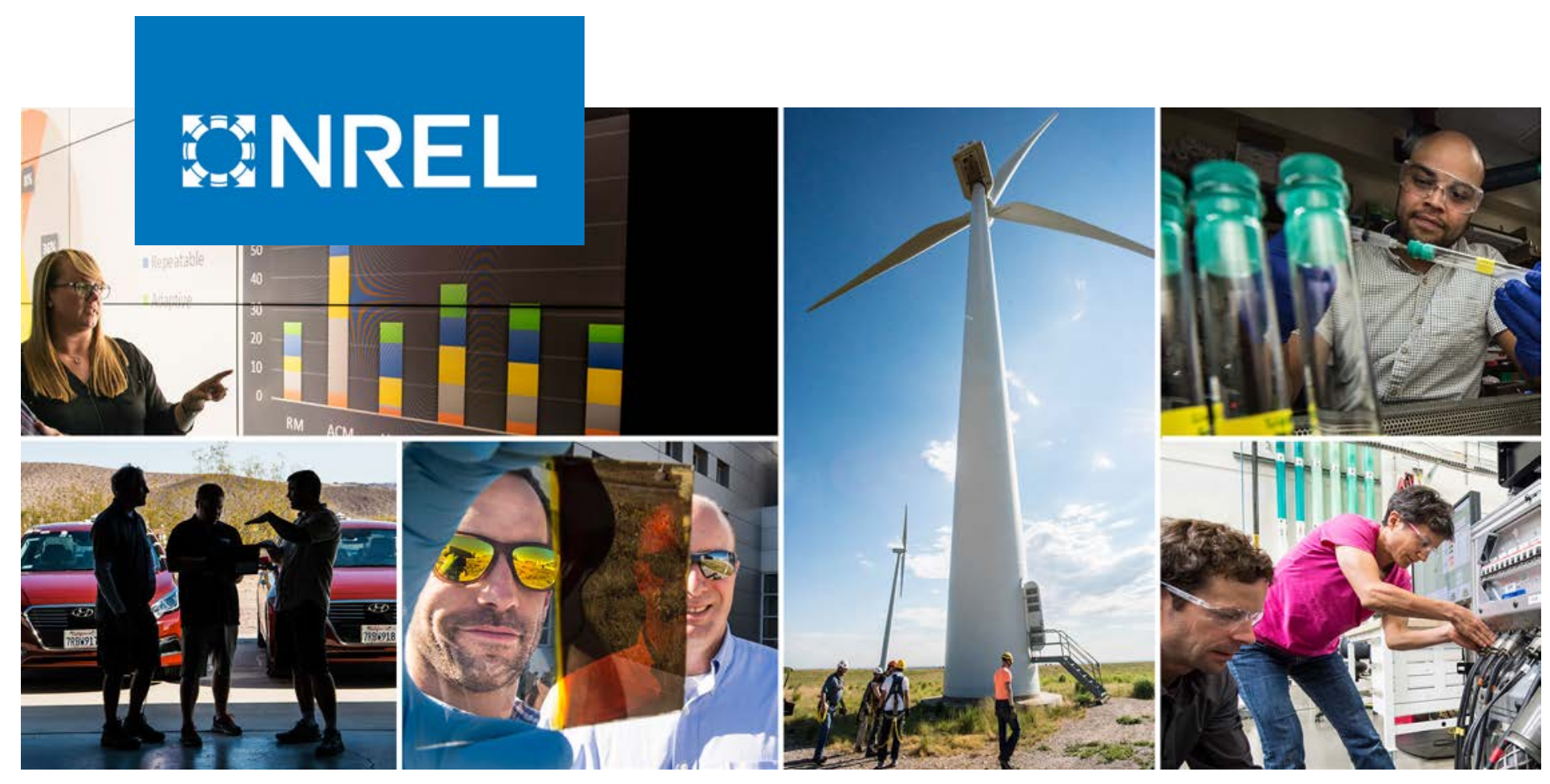

\title{
Algal Biomass Production via Open Pond Algae Farm Cultivation: 2019 State of Technology and Future Research
}

Ryan Davis and Lieve Laurens

NREL is a national laboratory of the U.S. Department of Energy Office of Energy Efficiency \& Renewable Energy

Operated by the Alliance for Sustainable Energy, LLC

This report is available at no cost from the National Renewable Energy Laboratory (NREL) at www.nrel.gov/publications.
Technical Report

NREL/TP-5100-76569

April 2020 


\title{
GNREL
}

\section{Algal Biomass Production via Open Pond Algae Farm Cultivation: 2019 State of Technology and Future Research}

\author{
Ryan Davis and Lieve Laurens
}

\section{Suggested Citation}

Davis, Ryan, and Lieve Laurens. 2020. Algal Biomass Production via Open Pond Algae Farm Cultivation: 2019 State of Technology and Future Research. Golden, CO: National Renewable Energy Laboratory. NREL/TP-5100-76569. https://www.nrel.gov/docs/fy20osti/76569.pdf

NREL is a national laboratory of the U.S. Department of Energy Office of Energy Efficiency \& Renewable Energy Operated by the Alliance for Sustainable Energy, LLC

This report is available at no cost from the National Renewable Energy Laboratory (NREL) at www.nrel.gov/publications.

Contract No. DE-AC36-08GO28308
Technical Report NREL/TP-5100-76569 April 2020

National Renewable Energy Laboratory 15013 Denver West Parkway Golden, CO 80401 303-275-3000 • www.nrel.gov 


\section{NOTICE}

This work was authored by the National Renewable Energy Laboratory, operated by Alliance for Sustainable Energy, LLC, for the U.S. Department of Energy (DOE) under Contract No. DE-AC36-08GO28308. Funding provided by U.S. Department of Energy Office of Energy Efficiency and Renewable Energy Bioenergy Technologies Office. The views expressed herein do not necessarily represent the views of the DOE or the U.S. Government.

This report is available at no cost from the National Renewable Energy Laboratory (NREL) at www.nrel.gov/publications.

U.S. Department of Energy (DOE) reports produced after 1991 and a growing number of pre-1991 documents are available free via www.OSTI.gov.

Cover Photos by Dennis Schroeder: (clockwise, left to right) NREL 51934, NREL 45897, NREL 42160, NREL 45891, NREL 48097, NREL 46526.

NREL prints on paper that contains recycled content. 


\section{Acknowledgements}

The authors wish to thank the following researchers for their contributions to this work: Phil Pienkos, Eric Knoshaug, Bruno Klein, and Zia Abdullah from the National Renewable Energy Laboratory (NREL); John McGowen from Arizona State University (ASU); Michael Huesemann from Pacific Northwest National Laboratory (PNNL); Taraka Dale from Los Alamos National Laboratory (LANL); and other partners in the Development of Integrated Screening, Cultivar Optimization, and Verification Research (DISCOVR) Consortium. This report provides a highlevel overview of research data across key algal biomass cultivation trials as utilized in updating NREL's State of Technology (SOT) benchmark models, based on inputs furnished from those researchers; however, it is not intended to present an exhaustive summary of all research activities, methods, or data outputs, and we defer to those and others' research works for further context. 


\section{List of Acronyms}

AFDW

ANL

ARID

ASU

$\mathrm{ATP}^{3}$

AzCATI

BAT

BETO

CAP

$\mathrm{CO}_{2}$

DISCOVR

FA

FAME

FFA

FY

HCSD

LCA

MBSP

MFSP

NREL

PNNL

SOT

TEA ash free dry weight

Argonne National Laboratory

Algal Raceway Integrated Design

Arizona State University

Algal Testbed Public-Private Partnership

Arizona Center for Algae Technology and Innovation

Biomass Assessment Team

Bioenergy Technologies Office

Combined Algae Processing

carbon dioxide

Development of Integrated Screening, Cultivar Optimization, and

Verification Research

Florida Algae (testbed site under ATP ${ }^{3}$ Consortium)

fatty acid methyl ester

free fatty acid

fiscal year

High-Carbohydrate Scenedesmus

life cycle assessment

minimum biomass selling price

minimum fuel selling price

National Renewable Energy Laboratory

Pacific Northwest National Laboratory

state of technology

techno-economic analysis 


\section{Executive Summary}

The annual State of Technology (SOT) assessment is an essential activity for platform research conducted under the Bioenergy Technologies Office (BETO). It allows for the impact of research progress (both directly achieved in-house at NREL and furnished by partner organizations) to be quantified in terms of economic improvements in the overall biofuel production process for a particular biomass processing pathway, whether based on terrestrial or algal biomass feedstocks. As such, initial benchmarks can be established for currently demonstrated performance, and progress can be tracked towards out-year goals to ultimately demonstrate economically viable biofuel technologies.

NREL's algae SOT benchmarking efforts focus both on front-end algal biomass production and separately on back-end conversion to fuels through NREL's "combined algae processing" (CAP) pathway. The production model is based on outdoor long-term cultivation data, enabled by comprehensive algal biomass production trials conducted under Development of Integrated Screening, Cultivar Optimization, and Verification Research (DISCOVR) consortium efforts, driven by data furnished by Arizona State University (ASU) at the Arizona Center for Algae Technology and Innovation (AzCATI) testbed site. The CAP model is based on experimental efforts conducted under NREL R\&D projects.

This report focuses on front-end algal biomass production, documenting the pertinent algal biomass cultivation parameters that were input to the NREL open pond algae farm model. Through partnerships under DISCOVR, collaborators at ASU furnished details on cultivation performance metrics including biomass productivity and harvest densities for recent growth trials done at the AzCATI site. The resulting biomass productivity rates were calculated as 15.9 $\mathrm{g} / \mathrm{m}^{2} /$ day (ash free dry weight [AFDW], annual average) for seasonal cultivation of Desmodesmus intermedius C046, Monoraphidium minutum 26B-AM, and Scenedesmus obliquus UTEX393 biomass strains, grown in September (fall), October through April (fall through spring), and May through August (spring-summer) respectively at the ASU site. After incorporating the production data into a techno-economic analysis (TEA) model for algal biomass production based on a hypothetical commercial facility consisting of 5,000 acres of cultivation pond area (based on NREL's 2016 algae farm design case), the resulting minimum algal biomass selling price (MBSP) was estimated at \$764/ton (AFDW basis) in 2016-year dollars assuming " $n$th plant" economics for a mature facility utilizing low-cost unlined ponds, coupled with a targeted biomass composition consistent with NREL's high-carbohydrate Scenedesmus, or HCSD biomass, projections to ensure consistent nutrient costing versus downstream recycle credits from conversion operations. Alternatively, a scenario assuming the use of fully lined ponds would translate to a SOT biomass cost of $\$ 961 /$ ton. Another alternative scenario was also considered based on evaporation rates and salt blowdown disposal requirements reflective of the Algal Testbed Public-Private Partnership (ATP ${ }^{3}$ ) consortium's previous Florida Algae (FA) site (the basis for prior 2015-2016 SOT data before being decommissioned and unavailable for later SOTs), which would reduce MBSP to \$670/ton for the unlined pond case or $\$ 866 /$ ton for the lined case, given significantly lower net evaporation rates (evaporation minus precipitation) and thus salt accumulation levels in the ponds, which is a critical factor to consider for saline cultivation. 
Relative to the fiscal year 2018 (FY18) SOT at $\$ 955 /$ ton or $\$ 824 /$ ton for ASU and FA evaporation scenarios respectively (unlined pond basis), the FY19 SOT substantially improves on this result by $20 \%$ and $19 \%$ respectively. This is primarily attributed to a significant $\mathbf{3 6 \%}$ improvement in annual cultivation productivity achieved at the AzCATI site (supported by the efforts under the DISCOVR consortium noted above focused on this metric) through cultivation campaigns aimed at maximizing seasonal strain performance based on known highperforming strains for given seasonal temperatures, as well as pond operational optimizations that were anticipated to support productivity enhancements and mitigate contamination. Coupled with improved operational understanding and logistical support for long-term cultivation trials, this translated to demonstrating such significant productivity improvements simultaneously alongside a $50 \%$ increase in the underlying experimental on-line time, with the number of cultivation production days behind the seasonal productivity data growing from 219 (FY18) to 328 (FY19), in-line with NREL's $n^{\text {th }}$-plant model basis of 330 days-per-year of production uptime. After including downstream dewatering/blowdown and short-term storage losses, the overall modeled biomass production output to conversion was calculated at 23.1 ton/acre-yr for both the ASU and FA evaporation basis. A key factor behind the improved on-line time and cultivation productivity (most notably increased in the summer) was the use of a fungicide to control contamination. While the cost of fungicide utilized experimentally in warm months was not explicitly included in this $n^{\text {th }}$-plant analysis, a preliminary sensitivity case estimates that its usage would incur a trivial penalty of roughly $\$ 4 /$ ton to overall MBSPs.

Finally, this milestone reports on key process sustainability indicators for the biomass production stage including annual biomass yields, facility power demand, and water consumption. In keeping with recent BETO guidance, formal life cycle assessment sustainability metrics such as greenhouse gas emissions or fossil energy consumption are not calculated here, but will be deferred to Argonne National Laboratory (whom NREL has already sent input/output inventory data to prior to this report writing). 


\section{Table of Contents}

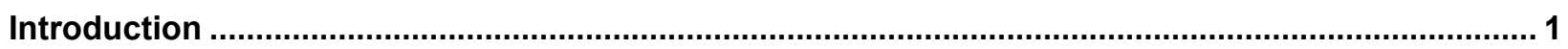

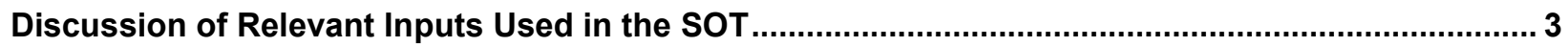

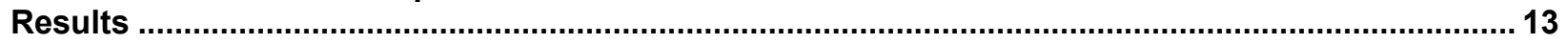

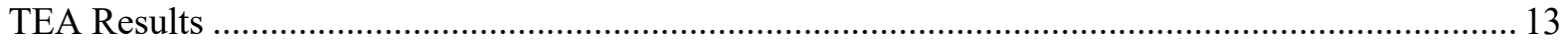

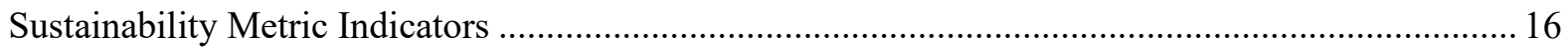

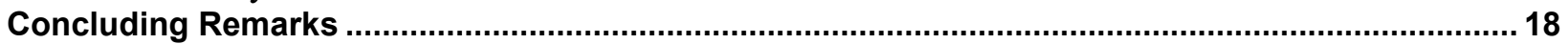

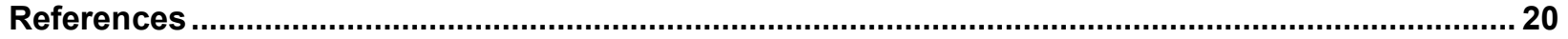

Appendix A. TEA Summary Sheet for Base Case Biomass Cultivation SOT Benchmark Model (FA

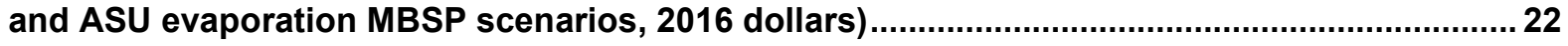

Appendix B. Life-Cycle Inventory (LCI) for 2019 SOT Algae Farm Model ....................................... 24 


\section{Introduction}

The National Renewable Energy Laboratory (NREL) develops and maintains techno-economic models that simulate the technical and economic aspects of conceptual biorefinery conversion pathways to biofuels and bioproducts, focused on both terrestrial and algal biomass processing routes. For a particular set of process parameters, material and energy balance and flow rate information are generated using Aspen Plus simulation software [1], for a given facility size or biomass throughput rate. These data are used to size and cost process equipment and compute raw material and other operating costs. Using a discounted cash flow rate of return analysis, the minimum fuel selling price (MFSP) or minimum biomass selling price (MBSP) required to obtain a net present value (NPV) of zero for a $10 \%$ internal rate of return (IRR) is determined. The result is a techno-economic model that reasonably estimates an " $n^{\text {th }}$-plant" production cost for this pre-commercial process.

Over recent years, NREL has published a number of design reports for both the production of algal biomass and the conversion of algae to fuels via the "combined algae processing" (CAP) pathway [2,3], both of which focused on out-year targets that, if achieved, would translate to a modeled MBSP of $\$ 494 /$ ton for biomass (2014\$, ash free dry weight [AFDW] basis) and MFSP of $\$ 5.90$ per gallon gasoline equivalent (GGE) for resulting fuels (after revising the original CAP design case to match up with the outputs from the newer algae farm design case, as documented in the 2016 Multi-Year Program Plan [4]). The latter MFSP projection was based on NREL's original CAP processing approach focused on fuels via well-understood conversion technologies, which is evolving towards a focus on hydrocarbon fuels and value-added coproducts to reduce the MFSP towards future targets. However, in order to achieve such fuel cost goals in the future, substantial improvements are required particularly around biomass cultivation costs, representing the largest contributor to overall fuel cost, driven most strongly in turn by the achievable annual cultivation productivity. Accordingly, this has been the primary parameter of focus in prior algae farm SOTs since 2015, as well as more broadly in the BETO Algae Platform as the subject of numerous funding grants over that timeframe.

Upon initiation of algal MBSP benchmarking with the FY15 SOT, the demonstrated annual productivity was $8.5 \mathrm{~g} / \mathrm{m}^{2} /$ day based on the first year of data generated under a prior consortium titled $\mathrm{ATP}^{3}$, translating to a modeled MBSP of $\$ 1,142 /$ ton in $2016 \$$. Relative to final future targets of $\$ 488 /$ ton at $25 \mathrm{~g} / \mathrm{m}^{2} /$ day (updated here to $2016 \$$ and $21 \%$ taxes, versus $\$ 494 /$ ton in $2014 \$$ noted earlier), this implied a need to improve productivity by roughly three-fold in order to reduce MBSP by $60 \%$. Initially, subsequent improvements made after the FY15 SOT point were modest relative to the degree of improvement ultimately required, but this in part reflected the fact that the initial focus of the Algal Testbed Public-Private Partnership (ATP ${ }^{3}$ ) was strictly to maintain uniformity across test-bed sites in establishing transparent benchmarks more than to improve performance. More recently, and particularly for the present FY19 SOT, efforts have shifted to specifically focus on improving cultivation productivity based on hypothesis-driven research to evaluate the most promising strains and cultivation conditions, translating to a more notable improvement in this year's 2019 SOT as presented below.

The biomass production SOT inputs for the present exercise were all sourced from the Arizona Center for Algae Technology and Innovation (AzCATI) testbed site operating outdoor ponds 
over seasonal periods spanning the course of a year. All cultivation trials selected for incorporation in this year's 2019 SOT benchmark leverage Arizona State University's (ASU's) expertise in performing the cultivation work under the support of the DISCOVR consortium (https://discovr.labworks.org/). In keeping with prior SOTs, the cultivation practices and data generation were all based on consistent methods that have been well-established by ASU across all season/strain cases. Beyond the crucial cultivation operation itself, other steps in the algae farm model are considered either outside the scope of battery limits (such as $\mathrm{CO}_{2}$ and nutrient delivery logistics), or otherwise outside the scope of experimental work and therefore available data to which we have access (namely algal biomass dewatering, which was maintained fixed in the biomass production SOT model consistent with the design case). The model will be improved in out-years with the incorporation of relevant data in these areas, replacing the assumptions currently in place.

We emphasize that the present SOT analysis and the resultant MBSP and MFSP values carry some uncertainty related to the assumptions and estimates made for capital and raw material costs. Without a detailed understanding of the underlying basis, the absolute computed selling price has limited relevance. By demonstrating the cost impact of various process parameters individually or in concert, the model helps guide research by indicating where the largest opportunities for cost reduction exist. It is also acknowledged that "State of Technology" is arguably a misnomer since no commercial algal biofuel facility exists today (e.g., growing algal biomass for purposes of producing fuels at commercial scale), and because the SOT performance results documented here are based solely on NREL and partner (DISCOVR) data and do not necessarily represent a broader picture of all performers within and beyond BETO's portfolio. 


\section{Discussion of Relevant Inputs Used in the SOT}

The algal biomass modeling work conducted for this SOT milestone makes use of the prior Aspen modeling framework that was originally established for the 2016 algae farm design report $[2,3]$. The process models remain separated between front-end cultivation and dewatering of algal biomass and back-end conversion of biomass via CAP. However, by utilizing the same biomass flow rates, concentrations, and costs (MBSP) as well as pertinent credits for nutrient and $\mathrm{CO}_{2}$ recycles consistently between the two sides of the process, the resulting MFSP is consistent with a single fully-integrated production and conversion facility.

The process schematic for the algal biomass production process as the subject of this SOT discussion is depicted in Figure 1. In summary, the overarching process for the production facility consists of 5,000 acres of production ponds (10 acres each in size) with a total facility footprint of 7,615 acres, coupled to an inoculum propagation system consisting of a series of closed and open growth systems of increasingly larger size, as well as dewatering operations made up of in-ground gravity settlers, hollow fiber membranes, and centrifugation in sequence to ultimately concentrate the biomass from the harvested density up to $20 \mathrm{wt} \%$ solids AFDW. The production facility also includes costs for $\mathrm{CO}_{2}$ (sourced from off-site flue gas carbon capture technology), fertilizer nutrients, delivery pipelines for makeup water from a nearby groundwater resource, and pipelines for on-site culture circulation and $\mathrm{CO}_{2}$ delivery to ponds. With the ponds representing the critical and most costly step of the process, the $n^{\text {th }}$-plant commercial facility stipulates the use of 10-acre ponds which are considerably larger than today's "large-scale" standards of 2-3 acre ponds in order to maximize economy of scale benefits, with an additional stipulation that the ponds are unlined (making use of native clay soils) except for small portions of the pond where a plastic liner is used to control erosion. While such a low-cost pond design may reasonably be viewed as representative of a future $n^{\text {th }}$-plant facility, a second alternative scenario also considers the use of fully-lined ponds which are more typical in today's early demonstration facilities (or which otherwise may more likely be required in the case of saline cultures). The cost and circulation power demands for the 10-acre ponds are based on average values attributed to four separate pond design estimates that were furnished to NREL from external consultants in support of the 2016 design report.

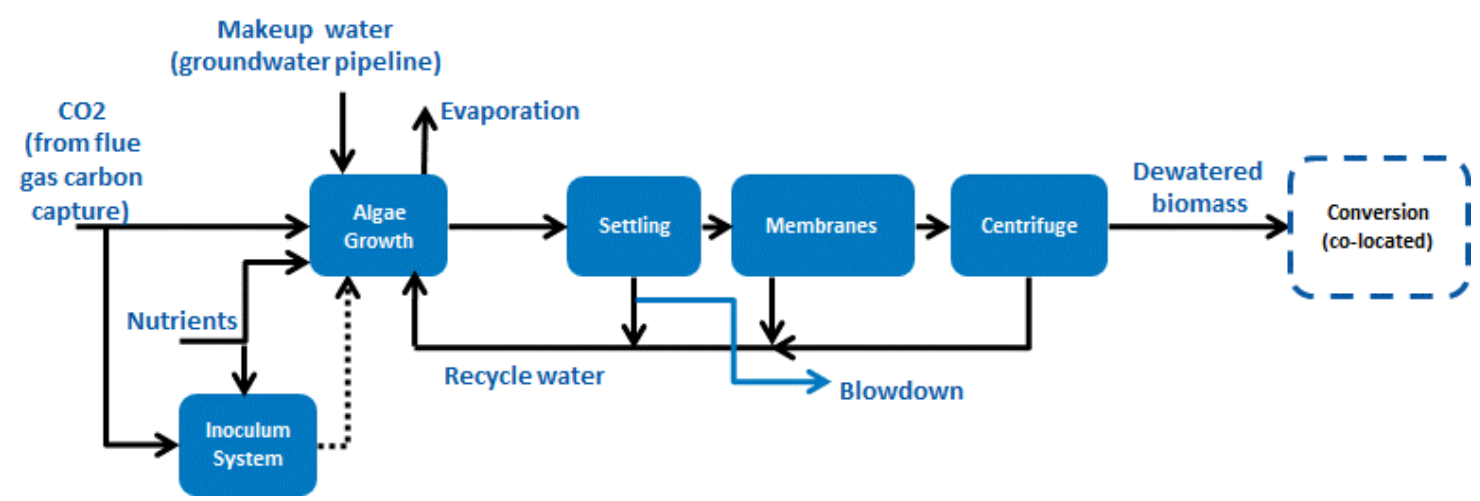

Figure 1. Schematic diagram summarizing key operations for algae biomass farm process model.

Experimental data outputs to SOT model are primarily focused on the main production pond step, with other operations either considered outside battery limits $\left(\mathrm{CO}_{2}\right.$, nutrient, water logistics) or otherwise outside the scope of currently available data (dewatering), and thus set consistent with future design case targets. 
As noted above, the inputs for the biomass production model were based on seasonal performance data generated under cultivation trials at the AzCATI testbed site over the past year (data from fall 2018 through summer 2019 feeding the FY19 SOT), with the key parameters utilized in the TEA model being productivity rates as well as biomass density at harvest and average daily pond evaporation. Additionally, biomass composition estimates are provided here; however, similar to previous SOT practices, the measured composition is based on biomass cultivated under nutrient-replete conditions, translating to high levels of protein and ash but relatively low levels of carbohydrates and lipids. More details on estimated and measured composition are provided below, but in summary, combined carbohydrate and lipid levels generally remain below 30\% for the seasonal strains reflected in the FY19 SOT, which is impractical for NREL's CAP model in its historical configuration focused to date on these two constituents while protein has traditionally been relegated to AD. Thus, also similar to prior SOTs, the base case FY19 SOT model assumes the composition of high-carbohydrate Scenedesmus (HCSD) for both the cultivation and CAP conversion process models, given that Scenedesmus was the basis used for CAP conversion experiments and this composition is also consistent with the targeted 2030 goals as described in the algae farm design case [3]. The SOT baseline cultivation model therefore assumes seasonal productivities, harvest densities, and evaporation rates attributed to the provided cultivation measurements across three seasonallyrotated strains (Desmodesmus, Monoraphidium, and Scenedesmus), overlaid with HCSD compositional assumptions for nutrient costing. The SOT CAP conversion model assumes this same HCSD composition and resulting seasonal flows from the farm model, with yields across each conversion step set based on experimental data also generally utilizing Scenedesmus. NREL has recently begun to move to a new CAP process configuration ultimately envisioned to allow more feedstock flexibility including the capability to upgrade protein to fuels alongside carbohydrates [22], but at the time of this writing data is not yet available for that new CAP approach due to recent logistical equipment issues.

Details on cultivation protocols and methods, as well as productivity calculations as used to inform the SOTs, are consistent with prior SOTs [5-7] and based on work performed by the same partners at ASU. The cultivation experiments are carried out in $4.2 \mathrm{~m}^{2}$ open ponds, with online monitoring of culture health. Operational conditions include semi-continuous operation over all seasons with up to $3 x$ per week harvesting and dilution of the cultures, from which the productivity is calculated as harvest yields based on ash-free dry weight. Additionally, while there was a substantial amount of other experimental activities and strains evaluated under the support of DISCOVR as well as other collaborations making use of ASU's test-bed facilities (e.g. eight strains in total were evaluated by ASU between September 2018 through August 2019 including other partnerships), this milestone report is not intended to provide an exhaustive summary of all such activities. We defer to the associated reports for those respective efforts to provide a more thorough documentation of all activities, methods, hypotheses investigated, lessons learned on what worked and did not work, etc. Only those details as pertinent to the cases/datasets selected to form the basis for the SOT inputs are discussed here.

In summary, the prior 2018 summer strain in rotation under DISCOVR efforts (Desmodesmus intermedius C046) was continued through September, thus representing the first month of fall 2018 cultivation data as incorporated into the present FY19 SOT update, with a resulting monthaverage productivity of $11.0 \mathrm{~g} / \mathrm{m}^{2} /$ day based on semi-continuous harvesting maintaining a $20 \mathrm{~cm}$ pond depth. Subsequently, beginning in October the work shifted to the use of a cold-season 
strain Monoraphidium minutum 26B-AM (a strain that was also seen to perform well in colder months in last year's SOT, and which continued to lead the cold-season candidates under DISCOVR screening activities), grown in brackish conditions up to $10 \mathrm{ppt}$ salinity (all strains reflected in this SOT were grown in saline conditions given BETO's focus on saline over freshwater). This strain was maintained through the remainder of the fall (defined here as September through November), all of the winter (December through February), and the first two months of spring (March and April maintaining this strain, with spring spanning through May), with data continuing to be collected for at least 23 days of each respective month and usually nearly the full month (24-31 days). Similar to cold-season operational practices as noted in the FY18 SOT report, the pond depth was reduced from $20 \mathrm{~cm}$ to $10 \mathrm{~cm}$ between November through April, running more shallow to increase peak daytime culture temperatures and improve light utilization given lower wintertime solar irradiance.

Resulting monthly and season-average productivities over all months utilizing Monoraphidium 26B-AM are reported in Table 1. As expected, during that period with shallower pond operation, harvest densities generally increased over $20 \mathrm{~cm}$ operation, translating to somewhat lower downstream processing throughputs through dewatering (however, the dewatering capital expenses were set based on maximum seasonal capacity in the summer and thus this leads to minimal overall MBSP savings). Given prior data under FY18 SOT efforts showing no distinguishable difference between standard raceway versus Algal Raceway Integrated Design (ARID) pond system performance during cold seasons [15], such pond design trials were not repeated this year. However, recognizing that at large commercial scale it would not likely be practical to operate a standard raceway pond at a shallow $10 \mathrm{~cm}$ depth (frictional drag losses would overcome culture momentum and circulation would cease over such a large area with a single paddlewheel station), an alternative design similar to ARID or a more generic gravitydriven serpentine pond may be required to allow such shallower culture depths. Given the findings in the 2016 algae farm design report which showed comparable pond costs between such sloped channel designs (serpentine, sloped raceways) versus flat paddlewheel raceways of the same size [3], it is reasonable to utilize the testbed data at $10 \mathrm{~cm}$ depth in the SOT models as such a pond design to accommodate that approach would not translate to appreciable underlying pond cost differences.

Notably, during the majority of the cold-season runs from fall through Spring with Monoraphidium 26B-AM, a second strain was also evaluated and performed nearly as well over much of that period, namely Scenedesmus obliquus UTEX393. Given that this Scenedesmus strain is actually better matched to warm-season months, it did not achieve the growth rate performance of 26B-AM until the end of spring (May), at which point the focus was switched to the use of this strain between May through the end of the summer (June - August). All months reflecting cultivation with UTEX393 were based on standard $20 \mathrm{~cm}$ pond depth operation given that both daytime culture temperatures and solar irradiance (being too low) were no longer issues in the summer months. Additionally, to sustain continued growth performance as temperatures began increasing, the use of a fungicide (Fluazinam) was required. This was generally utilized at a 1 ppm dosing roughly every 1-2 weeks over the course of the summer from early June through late August. It is likely that both the use of this Scenedesmus strain as well as the Fluazinam fungicide contributed to highly favorable performance in the summer months observed during this SOT campaign (see Table 1 and discussion below). Owing to the $n^{\text {th }}$-plant assumptions underpinning the SOT analysis, which in this case makes the assumption that sufficient strain 
development has occurred to make use of robust algal strains resistant to culture crashes under an $n^{\text {th }}$-plant level of technology maturity, the associated usage and cost for fungicide is not currently reflected in the present SOT exercise. A sensitivity case for Fluazinam inclusion is provided below. Moving forward, such details are planned to be incorporated with more granularity into a "pre- $n$th -plant" operational baseline as part of future DISCOVR work under the newly-added TEA subtask, to better track more specific operational strategies such as this and associated performance-cost tradeoffs in order to better quantify economic impacts on algae farm MBSP attributed to DISCOVR developments. Similarly, opportunities for future investigation under DISCOVR could warrant a more detailed TEA assessment of cost-tradeoffs for seasonal strain rotation versus use of a single strain year-round.

Table 1. Monthly Cultivation Performance for FY19 SOT Trials (source: John McGowen, ASU)

\begin{tabular}{|l|c|c|c|c|c|c|} 
Season & Month & $\begin{array}{c}\text { Productivity, } \\
\mathbf{g} / \mathbf{m}^{2} \text {-day }\end{array}$ & $\begin{array}{c}\text { AFDW at } \\
\text { Harvest, g/L }\end{array}$ & Strain & Days & $\begin{array}{c}\text { Season } \\
\text { Avg. }\end{array}$ \\
\hline \multirow{3}{*}{ Summer } & August & 24.3 & 0.37 & UTEX393 & 28 & 27.1 \\
& July & 30.6 & 0.48 & UTEX393 & 30 & \\
& June & 26.3 & 0.43 & UTEX393 & 27 & \\
\hline \multirow{3}{*}{ Spring } & May & 26.3 & 0.46 & UTEX393 & 28 & 18.7 \\
& April & 17.6 & $0.66(10 \mathrm{~cm})$ & 26 BAM & 28 & \\
\hline \multirow{3}{*}{ Winter } & March & 12.3 & $0.68(10 \mathrm{~cm})$ & 26 BAM & 31 & \\
& February & 6.4 & $0.43(10 \mathrm{~cm})$ & 26 BAM & 28 & 6.5 \\
& January & 7.3 & $0.52(10 \mathrm{~cm})$ & 26 BAM & 24 & \\
\hline \multirow{3}{*}{ Fall } & December & 5.7 & $0.58(10 \mathrm{~cm})$ & 26 BAM & 38 & \\
& November & 9.8 & $0.57(10 \mathrm{~cm})$ & 26 BAM & 27 & 11.4 \\
& October & 13.3 & 0.38 & 26 BAM & 23 & \\
& September & 11.0 & 0.29 & C046 & 16 & \\
\hline
\end{tabular}

Text overlays by harvest density values indicate cold-season months with $10-\mathrm{cm}$ pond depth (otherwise 20 -cm pond depth standard). Strain IDs = Scenedesmus obliquus UTEX393, Monoraphidium minutum 26B-AM, and Desmodesmus intermedius C046.

Table 2 presents a summary of the cultivation productivity, harvest density, and daily evaporation rates on a seasonal-average basis attributed to the ASU data used in the 2019 SOT, in comparison to prior data used in the 2017-2018 SOTs (generally utilizing 2016 and 2017 data respectively) also at the ASU site, as well as the 2015 and 2016 SOTs (utilizing 2014 and 2015 data respectively). As noted in prior SOT milestone reports, the first two years constituting the 2015-2016 SOTs were based on cultivation work done at ATP"'s Florida Algae ("FA") testbed site, given improved productivities and climate conditions that had been observed at that site while it was operating; however, that site was subsequently decommissioned as the land it occupied was no longer available for $\mathrm{ATP}^{3}$ use, which prompted a change to the ASU testbed site for all cultivation work supporting the 2017 SOT onward. This incurs an obvious but unavoidable disconnect in consistently comparing cultivation performance throughout the full span of the reported years, given different weather variables (solar irradiance, temperatures, 
seasonal swings, etc.) between the two testbed locations. Discussions are continuing with BETO and Pacific Northwest National Laboratory's (PNNL's) Biomass Assessment Team (BAT) to establish a credible approach to control for locational and single-year weather variables in order to extrapolate the measured cultivation performance for a given year to a single consistent location over a 30-year average weather span, as may be useful for future SOT efforts moving forward.

Based on the selected cases for the FY19 SOT as shown in Table 2, the resulting year-average productivity is $15.9 \mathrm{~g} / \mathrm{m}^{2} /$ day, which represents a notable $36 \%$ improvement over the FY18 SOT basis of $11.7 \mathrm{~g} / \mathrm{m}^{2} /$ day, with improvements in productivity demonstrated for each individual season aside from a slight drop in winter. Namely, spring and fall season average productivity increased by $23 \%$ and $34 \%$, respectively, while winter decreased by $16 \%$; the most substantial difference was the summer average productivity, which increased by $76 \%$ relative to the FY 18 SOT to $27.1 \mathrm{~g} / \mathrm{m}^{2} /$ day, surpassing by 6 years a BETO 2025 goal of $25 \mathrm{~g} / \mathrm{m}^{2} /$ day in the summer (as noted above, likely due to both a high-performing summer strain selected by DISCOVR as well as improved understanding at the ASU testbed on the use of fungicide to control for contamination, which may also improve growth rates in addition to reducing crash events). It is also worth pointing out that these seasonal productivity data were tied to a total of 328 days of experimental on-line production time (all of which are included in the average seasonal values), a 50\% increase over the FY18 SOT basis of 219 days; this brings the experimental uptime in line with the fixed $n^{\text {th }}$-plant model assumption at 330 days/year. Moreover, the FY19 SOT dataset reflects new cultivation data for all four seasons for the first time since the FY15 SOT (for various logistical reasons, the FY16-18 SOT campaigns had to pull from a prior year's dataset to fill in gaps for one missing season for which no new data had been collected). This latest performance level is on-par or beginning to exceed the best data previously reported elsewhere publicly [8-11], and is based on transparent data and calculation methods provided first-hand. A direct comparison against such other reported values is obfuscated by different locations, pond designs, harvesting protocols, and calculation methodologies for productivity. Also notably, relative to the initial 2015 SOT benchmark at $8.5 \mathrm{~g} / \mathrm{m}^{2} /$ day, the 2019 SOT case represents a considerable $87 \%$ improvement in four years. 
Table 2. Cultivation Productivity (AFDW), Harvest Density (AFDW), and Daily Evaporation Rate for Selected 2019 Cultivation Trials at ASU Site, Compared against Prior Cultivation Trials at ASU and Florida Algae Sites as well as Alternate FY16 SOT Data Furnished by an ABY1 Performer

\begin{tabular}{|c|c|c|c|c|c|c|c|}
\hline & $\begin{array}{l}\text { Productivity, } \\
\text { g/m²/day }\end{array}$ & $\begin{array}{c}\text { Harvest } \\
\text { Density, } \\
\text { g/L }\end{array}$ & $\begin{array}{l}\text { Evaporation } \\
\text { Rate, } \\
\text { cm/day }\end{array}$ & $\begin{array}{l}\text { Algae } \\
\text { Strain }\end{array}$ & $\begin{array}{l}\text { Harvests } \\
\text { per week }\end{array}$ & $\begin{array}{l}\text { Harvest } \\
\text { volume, } \\
\text { fraction of } \\
\text { pond }\end{array}$ & $\begin{array}{l}\text { Daily dilution } \\
\text { rate, fraction of } \\
\text { pond }\end{array}$ \\
\hline \multicolumn{8}{|c|}{2015 SOT (Florida Algae/ATP ${ }^{3}$ ) } \\
\hline Fall 2014 & 6.8 & 0.22 & 0.01 & Nanno & $1 \mathrm{x}$ & 0.75 & 0.11 \\
\hline Winter 2014 & 5.0 & 0.23 & 0.01 & Nanno & $1 \mathrm{x}$ & 0.75 & 0.11 \\
\hline Spring 2014 & 11.4 & 0.36 & 0.14 & Nanno & $1 \mathrm{x}$ & 0.75 & 0.11 \\
\hline Summer 2014 & 10.9 & 0.25 & 0.02 & Nanno & $1 \mathrm{x}$ & 0.75 & 0.11 \\
\hline $\begin{array}{c}\text { Average } \\
\text { 2016 SOT (Florid }\end{array}$ & \multicolumn{6}{|c|}{2016 SOT (Florida Algae/ATP 3 ) } & \\
\hline Fall 2015 & 7.0 & 0.20 & 0.01 & Desmo & $3 x$ & 0.50 & 0.21 \\
\hline Winter 2014a & 5.0 & 0.23 & 0.01 & Nanno & $1 \mathrm{x}$ & 0.75 & 0.11 \\
\hline Spring 2015 & 11.1 & 0.28 & 0.14 & Nanno & $3 x$ & 0.25 & 0.11 \\
\hline Summer 2015 & 13.3 & 0.32 & 0.02 & Desmo & $3 x$ & 0.50 & 0.21 \\
\hline Average & 9.1 & 0.26 & 0.04 & & & & \\
\hline \multicolumn{8}{|c|}{2016 SOT Reference Case (ABY1 Performer) } \\
\hline Fall & 7.8 & 0.20 & 0.01 & Nanno & \multicolumn{3}{|c|}{ Not provided } \\
\hline Winter & 4.8 & 0.23 & 0.01 & Nanno & \multicolumn{3}{|c|}{ Not provided } \\
\hline Spring & 13.0 & 0.28 & 0.14 & Nanno & \multicolumn{3}{|c|}{ Not provided } \\
\hline Summer & 17.5 & 0.32 & 0.02 & Nanno & \multicolumn{3}{|c|}{ Not provided } \\
\hline Average & 10.8 & $0.26^{b}$ & $0.04^{b}$ & & & & \\
\hline \multicolumn{8}{|c|}{2017 SOT (ASU/ATP $\left.{ }^{3}\right)$} \\
\hline Fall 2016 & 8.5 & 0.30 & 0.7 & Nanno & \multicolumn{3}{|c|}{ NA (batch mode, harvested every 1-3 weeks) } \\
\hline Winter 2016 & 5.5 & 0.36 & 0.2 & Kirch & \multicolumn{3}{|c|}{ NA (batch mode, harvested every $2-3$ weeks) } \\
\hline Spring 2016 & 13.2 (ARID) & 0.74 & 0.9 & Scened & $5 x$ & 0.25 & 0.18 \\
\hline Summer $2015^{c}$ & 14.1 & 0.32 & 1.2 & Desmo & $3 x$ & 0.50 & 0.21 \\
\hline Average & 10.3 & 0.43 & $0.7^{e}$ & & & & \\
\hline \multicolumn{8}{|c|}{2018 SOT (ASU/ATP³-DISCOVR-RACER) } \\
\hline Fall $2016^{\mathrm{d}}$ & 8.5 & 0.30 & 0.7 & Nanno & \multirow{2}{*}{\multicolumn{3}{|c|}{$\begin{array}{c}\text { NA (batch mode, harvested every } 1-3 \text { weeks) } \\
\text { NA (batch mode, harvested every } 10-13 \\
\text { days) }\end{array}$}} \\
\hline Winter 2018 & 7.7 & 0.69 & 0.2 & $\begin{array}{l}\text { Scened/ } \\
\text { Monor }\end{array}$ & & & \\
\hline Spring 2018 & 15.2 & 0.70 & 0.9 & Monor & $1-3 x$ & 0.83 & 0.17 \\
\hline Summer 2018 & 15.4 & 0.35 & 1.2 & Desmo X2 & $3 x$ & 0.55 & 0.20 \\
\hline \multicolumn{8}{|c|}{2019 SOT (ASU/DISCOVR) } \\
\hline Fall 2018 & 11.4 & 0.41 & 0.7 & $\begin{array}{c}\text { Desmo/ } \\
\text { Monor }\end{array}$ & $2.4 \times($ avg) & 0.50 & 0.17 \\
\hline Winter 2019 & 6.5 & 0.51 & 0.2 & Monor & $1.3 x(a v g)$ & 0.65 & 0.12 \\
\hline Spring 2019 & 18.7 & 0.60 & 0.9 & $\begin{array}{c}\text { Scened/ } \\
\text { Monor }\end{array}$ & $2.0 x($ avg) & 0.63 & 0.18 \\
\hline $\begin{array}{c}\text { Summer } 2019 \\
\text { Average }\end{array}$ & $\begin{array}{l}27.1 \\
15.9\end{array}$ & $\begin{array}{l}0.43 \\
\mathbf{0 . 4 9}\end{array}$ & $\begin{array}{l}1.2 \\
\mathbf{0 . 7}\end{array}$ & Scened & $3.0 x($ avg) & 0.75 & 0.32 \\
\hline
\end{tabular}


The compositional data corresponding with the FY19 SOT productivity data shown in Tables 1 and 2 for the DISCOVR cultivation experiments is presented below in Table 3. Fall data includes the month of September 2018 for Desmodesmus C046 (shown in parentheses for the fall column), and October-November 2018 for Monoraphidium 26B-AM. Winter reflects exclusive use of Monoraphidium 26B-AM, as well as the majority of spring (March-April 2019), after which point Scenedesmus UTEX393 is reflected for the final month of spring (May 2019, shown in parentheses for the spring column) and all of summer (June-August 2019). All compositional data shown in Table 3 reflect measured averages for at least 10 different harvest points throughout the respective cultivation periods ( $>35$ for spring data sets), with the exception that for the Scenedesmus UTEX393 summer runs, only 6 harvest samples were included in the averaged data. Generally no significant trends in biomass composition across the 4 seasons can be observed because of the wide range of physiology that is underlying the harvested biomass samples. The exception in compositional trends can be found in the total C content of Monoraphidium 26B-AM which is consistently higher than Scenedesmus UTEX393, with the highest observed $\mathrm{C}$ content of over $55 \%$ and a significant increase in the late-spring months. Further details and caveats behind the compositional values reported here are shown in the footnotes of Table 3.

Similar to previous SOTs, all cultivation experiments were conducted in nutrient-replete conditions, generally translating to similar component compositions as have been reported previously with respect to high protein and relatively low lipid and carbohydrate contents. Namely, FAME lipid content (reported here as FFA) is consistently shown to vary between 6 and 9 dry wt $\%$, and fermentable carbohydrates (glucose plus mannose) are between 17 and 21 dry $\mathrm{wt} \%$, while protein content is higher between 36-45 dry wt $\%$. Although such measured biomass compositions were expected given the focus on maximizing productivity supported by nutrientreplete conditions, they continue to reflect a difference relative to the future target composition exemplified by mid-harvest, high-carbohydrate Scenedesmus (HCSD) projected to be achieved by 2030 (Table 4 ) with a lower protein content (13 dry wt \%) and higher lipid (26\% FAME as FFA) and carbohydrate (48\%) content [3] (the HCSD composition shown in Table 4 is consistent with the algae farm design report [3], but with additional detail added now to reflect components not previously specified explicitly such as glycerol and sterols [12]). As the latter for mid-to-late harvest (and thus nutrient deplete) Scenedesmus continues to be the SOT basis for experimental CAP conversion processes given that the experimentally cultivated high-protein material is not practical for such processes (at least based on historical CAP approaches taken to date), as noted above and similar to prior SOT practices, the base case SOT biomass model conducted here maintains the values for seasonal cultivation productivity performance and pond densities as demonstrated at ASU, but overlaid with the HCSD biomass compositional attributes for purposes of running the same HCSD composition through the CAP model as well, and to ensure consistent treatment between raw cultivation nutrient $/ \mathrm{CO}_{2}$ costs versus recycle credits from downstream conversion. The HCSD composition is also consistent with the basis utilized in the 2016 algae farm design case. As an alternate sensitivity case, if the harvested compositions as shown in Table 3 were reflected through the SOT models, the resultant MBSPs would increase by approximately $\$ 91 /$ ton relative to the HCSD basis, primarily by way of increased N/P nutrient demands (although noting that the majority of this increase would subsequently be offset by nutrient recycle credits taken in downstream conversion models). 
Table 3. Elemental and Component Compositions based on Seasonal Average Values for Harvested Strains Reported in Table 1 (adjusted to 100\% Mass Balance Closure) [12, 3].

\begin{tabular}{|c|c|c|c|c|}
\hline Elemental (AFDW) ${ }^{a, b}$ & $\begin{array}{c}\text { Fall } \\
\text { Monor/Desmo }\end{array}$ & $\begin{array}{l}\text { Winter } \\
\text { Monor }\end{array}$ & $\begin{array}{c}\text { Spring } \\
\text { Monor/Scened g }\end{array}$ & $\begin{array}{l}\text { Summer } \\
\text { Scened }\end{array}$ \\
\hline $\mathrm{C}$ & $52.2(49.2)$ & 52.7 & $54.1(52.9)$ & 48.3 \\
\hline $\mathrm{H}$ & $7.8(7.5)$ & 7.8 & $7.9(7.7)$ & 7.2 \\
\hline $\mathrm{O}$ & $29.7(32.6)$ & 29.4 & $27.0(27.7)$ & 33.6 \\
\hline $\mathrm{N}$ & $8.9(9.4)$ & 8.7 & $9.7(10.2)$ & 9.5 \\
\hline S & $0.2(0.2)$ & 0.2 & $0.2(0.2)$ & 0.2 \\
\hline$P$ & $1.2(1.2)$ & 1.2 & $1.2(1.2)$ & 1.2 \\
\hline Total & $100.0 \%$ & $100.0 \%$ & $100.0 \%$ & $100.0 \%$ \\
\hline \multicolumn{5}{|l|}{ Component (dry wt) ${ }^{b}$} \\
\hline Ash & $14.9(17.5)$ & 8.6 & $12.5(9.2)$ & 8.4 \\
\hline Protein & $35.6(36.9)$ & 42.4 & $37.5(44.5)$ & 41.7 \\
\hline FAME lipids ${ }^{c}$ & $8.5(6.4)$ & 8.8 & $6.8(8.0)$ & 9.3 \\
\hline Glycerol c & $1.0(0.7)$ & 1.0 & $0.8(0.9)$ & 1.1 \\
\hline Non-fuel polar lipid impurities & $5.1(3.9)$ & 5.3 & $4.1(4.8)$ & 5.6 \\
\hline Sterols ${ }^{d}$ & $0.5(0.5)$ & 0.5 & $0.5(0.5)$ & 0.5 \\
\hline Fermentable carbohydrates e & $21.2(17.5)$ & 21.0 & $19.4(18.7)$ & 17.0 \\
\hline Other carbohydrates (galactose) & $4.0(3.3)$ & 3.9 & $3.6(3.5)$ & 3.2 \\
\hline Cell mass & $9.3(13.2)$ & 8.6 & $14.7(10.0)$ & 13.3 \\
\hline Total & $100.0 \%$ & $100.0 \%$ & $100.0 \%$ & $100.0 \%$ \\
\hline
\end{tabular}

${ }^{a} \mathrm{CHN}$ composition is reported as measured $\mathrm{CHN}$ data corrected for ash content of the biomass, $\mathrm{O}$ was calculated as the difference from mass balance after estimating $S$ and $P$ (as 0.2 and $1.2 \%$, respectively) and adjusted to $100 \%$ b SOT biomass compositions are less detailed than the HCSD basis; CHN and composition data for Scenedesmus and Monoraphidium cases are based on measured averaged data for harvested production samples and are considered representative for primarily nutrient replete growth conditions. Composition data as currently broken down to ash, protein, lipids as FAME (in this case TAG lipids measured as FAME, with an added estimate of $10 \%$ glycerol relative to measured FAME, and an assumed polar lipid headgroup fraction that increased the FAME content by at least $60 \%$ ), and total carbohydrate content (reported here as $80 \%$ fermentable from the measured sum of monosaccharides detected, $20 \%$ non-fermentable and an additional $10 \%$ assumed unhydrolyzable or recalcitrant), a remaining component called 'cell mass' accounts for between $5 \%$ and $18 \%$ of the biomass and reflects unidentified components that are not measured but are need to account for the mass balance.

${ }^{\mathrm{c}}$ Lipids originally characterized as triglycerides (1:1 FAME equivalent); adjusted here to FFA plus glycerol (as $\sim 11 \%$ of the measured FAME content, and reflective of actual components in pretreated hydrolysate for Scenedesmus biomass.

dSterols originally included in "polar lipid impurity" fraction in prior models. Value currently estimated for HCSD, based on a representative earlier-harvest biomass sample, for SOT biomass, sterol concentration is estimated at a flat $0.5 \%$ of the biomass, consistent with earlier observations at NREL

e "Fermentable carbohydrates" typically consist of $75 \%$ glucose, $25 \%$ mannose, for all species analyzed in FY19

${ }^{f}$ Fall: first value: Monoraphidium 26BAM (Oct-Nov), value in parentheses: Desmodesmus C046 (Sept)

g Spring: first value: Monoraphidium 26BAM (Mar-Apr), value in parentheses: Scenedesmus UTEX393 (May) 
Table 4. Elemental and Component Compositions for High-Carbohydrate Scenedesmus (HCSD) Biomass (Used for the SOT Base Case Model), Adjusted to 100\% Mass Balance Closure, per NREL Algae Farm Design Case [3].

\begin{tabular}{ll}
\hline Elemental (AFDW) & HCSD Basis Composition \\
\hline $\mathrm{C}$ & 54.0 \\
$\mathrm{H}$ & 8.2 \\
$\mathrm{O}$ & 35.5 \\
$\mathrm{~N}$ & 1.8 \\
$\mathrm{~S}$ & 0.2 \\
$\mathrm{P}$ & 0.22 \\
Total & $100.0 \%$ \\
\hline Component (dry wt) & \\
\hline Ash & 2.4 \\
Protein & 13.2 \\
FAME lipids & $26.0^{\mathrm{a}}$ \\
Glycerol & $3.0^{\mathrm{a}}$ \\
Non-fuel polar lipid impurities & $1.0^{\mathrm{a}}$ \\
Sterols & $1.8^{\mathrm{b}}$ \\
Fermentable carbohydrates & $47.8^{\mathrm{c}}$ \\
Other carbohydrates (galactose) & $3.2^{\mathrm{a}}$ \\
Cell mass & $1.6^{\mathrm{a}}$ \\
Total & $100.0^{\circ}$ \\
\hline
\end{tabular}

a Lipids originally characterized as triglycerides (1:1 FAME equivalent); adjusted here to FFA plus glycerol (reflective of actual components in pretreated hydrolysate for Scenedesmus biomass).

b Sterols originally included in "polar lipid impurity" fraction in prior models. Value currently estimated for HCSD, based on a representative earlier-harvest biomass sample.

c "Fermentable carbohydrates" consists of $75.1 \%$ glucose, $24.9 \%$ mannose

For modeling purposes, the SOT cultivation data for the parameters noted above were input into the "Area 100" section of the biomass production model (cultivation ponds); all other portions of the model were unchanged relative to details described in the design report [3], including makeup $\mathrm{CO}_{2}$ and water delivery costs to the facility as well as dewatering design and performance (maintaining the use of in-ground gravity settlers, followed by hollow fiber membranes and then centrifugation to concentrate the biomass to $1 \%, 13 \%$, and then $20 \%$ AFDW, respectively). The inoculum system capital and operating costs were maintained at the same fraction of production pond costs as the design case basis. Facility circulation pipelines were re-sized to reduce pipeline diameters associated with lower overall flows and circulation rates for the SOT models relative to the design case. Additionally, $\mathrm{CO}_{2}$ utilization in the pond was maintained at an assumed $90 \%$ of the feed $\mathrm{CO}_{2}$. The production ponds assumed in the model were based on 10-acre individual open raceway ponds, grouped into 50 "modules" within the overall 5,000 acre farm (based on cultivation area).

As noted above, initial SOTs in FY15-16 had utilized cultivation data from the Florida Algae (FA) testbed site before transitioning to the ASU site for the FY17-19 SOTs, given advantages for the FA site being located in the region (Gulf Coast) that has historically been viewed as most optimal for siting commercial algae farms given high productivities and low water consumption 
$[13,14]$. In addition to the disconnects this switch incurs with respect to locational variables that influence seasonal cultivation productivity, another artifact of the transition to the ASU site which also artificially influences biomass costs is the evaporation rates, which are significantly higher in Arizona than in Florida (where "evaporation rate" here is defined as net evaporation minus precipitation to replenish pond water levels). Namely, the net annual average pan evaporation estimated for the ASU site is $0.73 \mathrm{~cm} /$ day, versus $0.04 \mathrm{~cm} /$ day previously utilized for the FA site (both largely based on evaporation rates taken from local BAT models for each location, again based on net evaporation less precipitation). For saline cultivation as is currently stipulated by BETO to be required for SOTs and design cases moving forward, higher evaporation rates translate to higher blowdown requirements from the system in order to maintain pond salt tolerance limits of the strain. This saline blowdown must be disposed of and cannot merely be discharged to local water bodies, unless the site is located on the coast and can be discharged to the ocean. The current farm models assume the use of deep-well saltwater injection similar to practices employed for hydraulic fracturing in petroleum extraction. At an assumed makeup salt content of $7.7 \mathrm{ppt}$ for locally-sourced saline groundwater and an operating expense of $\$ 1.80 / \mathrm{m}^{3}$ blowdown water disposal, the blowdown requirements for a farm located in Arizona add significant costs to the overall MBSPs relative to a farm located in Florida for saline cultivation scenarios.

To mitigate this cost as much as possible, in the present SOT the blowdown is first routed to evaporation ponds to reduce the overall volume of water being disposed of (based on the same seasonal evaporation rates as the production ponds), costed at $\$ 49,455 /$ acre assuming fully-lined but simple shallow pits. The ponds are sized to reduce overall water content by $75 \%$ (near solubility limits for the dissolved salts). Additionally, the organism salt tolerance was assumed to be $50 \mathrm{ppt}$, which is higher than typical saline strains but within limits recently observed for a hypersaline strain up to $78 \mathrm{ppt}$ and consistent with recent observations at PNNL for a marine strain which indicated no detriment to growth rates at $50 \mathrm{ppt}$ salt levels. A second scenario is also considered based on evaporation rates previously modeled for the Florida Algae site, to control for the influence of this variable in the overall MBSP estimates in comparing to the FA basis in prior SOTs. Moving forward, one possible mitigation strategy to control for such artificial location/weather variables may be to engage with PNNL's BAT team to (a) validate the BAT growth model reflecting actual cultivation performance at a given site for the given year's weather data, and then (b) to extrapolate that data out to a common location (such as the FA site) to predict what the anticipated cultivation performance would be were it to have been run at that location given that location's weather data (ideally for 30-year average weather rather than a single year). Additionally, the BAT model could also be leveraged to help fill in missing gaps in cultivation data, i.e., in instances when data could not be collected in a particular month to better fill out a full "representative" season spanning all months based on BAT predictions for the missing data (although this was not an issue with the FY19 SOT reflecting good data coverage over the course of the full year). 


\section{Results}

\section{TEA Results}

Based on the key inputs from the cultivation activities noted above that were applied through NREL's biomass production model (i.e., utilizing the SOT productivity, harvest density, and [BAT-modeled] pond evaporation data for the seasonal strain production cases, coupled with the fixed HCSD compositional attributes as discussed above), the resulting MBSP costs are presented in Figure 2. For reference, Figure 2 also shows the estimated SOT costs for an alternative fully lined pond scenario, as well as the final target design case projections for the same HCSD biomass as established in the biomass design report [3] (although now adjusting the target year to 2030 for ultimately achieving $25 \mathrm{~g} / \mathrm{m}^{2} /$ day annual productivity). All current, backcast, and future costs are adjusted here to the latest financial parameters based on $2016 \$$ and $21 \%$ tax rates, as are being applied universally for all BETO Platform models. The resulting MBSP was estimated as \$764/ton AFDW in 2016\$ for the "unlined pond" base case when reflecting ASU evaporation rates/blowdown demands, which would reduce to $\$ 670 /$ ton if instead reflecting FA evaporation rates as were the basis for the 2015-2016 SOTs; compared to the 2030 design case target of $\$ 488 /$ ton (again in 2016\$, maintained as the basis for the remainder of this discussion unless otherwise noted). SOT costs for the "fully lined" alternative scenario would increase by $28 \%$ to $\$ 961 /$ ton or $\$ 866 /$ ton for the ASU and FA evaporation basis, respectively. While the cost of Fluazinam usage during warm season months is not presently included in this $n^{\text {th }}$-plant analysis (this will be evaluated in further detail under future DISCOVR TEA activities), a preliminary sensitivity analysis reflecting the added costs of Fluazinam was conducted. Based on an approximate average dosing frequency of 1.5 weeks at a 1ppm dosing concentration between May through August for Scenedesmus UTEX393, coupled with an assumed fungicide cost of $\$ 10 / \mathrm{kg}$, including an explicit cost for Fluazinam usage during warm months would add an estimated \$4/ton to the overall MBSP (less than $1 \%$ MBSP increase).

The SOT cost values are strongly tied to productivity, estimated at an annual average of 15.9 $\mathrm{g} / \mathrm{m}^{2} /$ day (AFDW) for the DISCOVR/ASU cultivation activities described above, representing a $36 \%$ improvement in annual average cultivation productivity relative to the FY18 SOT basis $\left(11.7 \mathrm{~g} / \mathrm{m}^{2} /\right.$ day) [15]. Notably, this also represents an $87 \%$ improvement relative to the initial 8.5 $\mathrm{g} / \mathrm{m}^{2} /$ day benchmark in the FY15 SOT as noted earlier. While this highlights substantial progress over the past four years, considerable improvements still remain to achieve the final goal of 25 $\mathrm{g} / \mathrm{m}^{2} /$ day by 2030 , or $20 \mathrm{~g} / \mathrm{m}^{2} /$ day by 2025 (as a plausible interim case on the path to 2030 ). Ongoing work under the DISCOVR consortium is aiming to set out-year goals around these parameters in order to keep progress on track over the next several years. Relative to historical progress made to date (productivity improvements of $7 \%, 13 \%, 14 \%$, and $36 \%$ in 2016-2019 relative to each preceding year), it is unlikely such substantial improvements will be sustainable on such a level moving forward indefinitely, but fortunately a lower degree of improvement on the order of $4 \%$ year-over-year will be all that must be demonstrated over the next 11 years in order to ultimately achieve the 2030 goal of $25 \mathrm{~g} / \mathrm{m}^{2} /$ day. DISCOVR is prepared to support continued improvements, with internal goals aspiring to exceed such levels over coming years. The data and resulting MBSP values presented here provide value as a public benchmark as they are based on transparent, long-term growth trials with public documentation of a vast dataset. 
Additionally, for the recent FY17-19 SOTs based on local evaporation rates pertinent to ASU's site, salt management/disposal costs were also seen to incur substantial cost penalties relative to those details at a gulf coast site with less net evaporation such as FA. As noted above, given significantly higher "net" evaporation rates (inclusive of precipitation considerations) for the ASU site (Phoenix, AZ) versus the FA site (Vero Beach, FL), this requires substantially more removal of blowdown as shown in Figure 1 to maintain salt levels within strain tolerance. In turn, the blowdown must be disposed of, assuming costs commensurate with deep-well saline injection. The costs for the injection/disposal step is maintained at $\$ 1.80 / \mathrm{m}^{3}(2016 \$)$ [16-20] consistent with the FY17 SOT discussion. In addition, as described earlier, two other mitigation measures were also maintained, including (a) evaporation ponds on the blowdown waste stream to reduce overall volumes, and (b) increasing salt tolerance limits up to $50 \mathrm{ppt}$ (utilized for both FA and ASU evaporation cases). Even after these measures, the MBSP contributions attributed to salt disposal are roughly \$26/ton higher for the FY19 SOT based on ASU versus FA evaporation. Given that this incurs such a large and artificial penalty on MBSP, to control for this variable and provide a more consistent comparison against the FY15-16 SOTs, the alternative FY19 SOT scenario based on FA evaporation rates is important to consider given that overall, this basis reduces MBSP costs by \$95/ton relative to the ASU evaporation basis. Thus, this reiterates an important conclusion that arid climates with high evaporation/low precipitation rates (such as the U.S. Southwest) are not an ideal location for siting algal cultivation facilities relative to lower-evaporation locations (such as the U.S. Gulf Coast), if focused on saline cultivation, due purely to challenges in how to manage salt; while prior BAT harmonization work had assumed this logic, i.e,. in placing a high priority on minimizing water losses, the present work quantifies the TEA penalty for this issue. However, given that the primary resources and expertise in algal cultivation to support the SOTs reside at ASU, we will continue to report on SOT MBSPs attributed both to Arizona and to Florida evaporation rates, assuming similar performance could be achieved at the latter location (again, BAT modeling may help resolve this in future SOTs). 


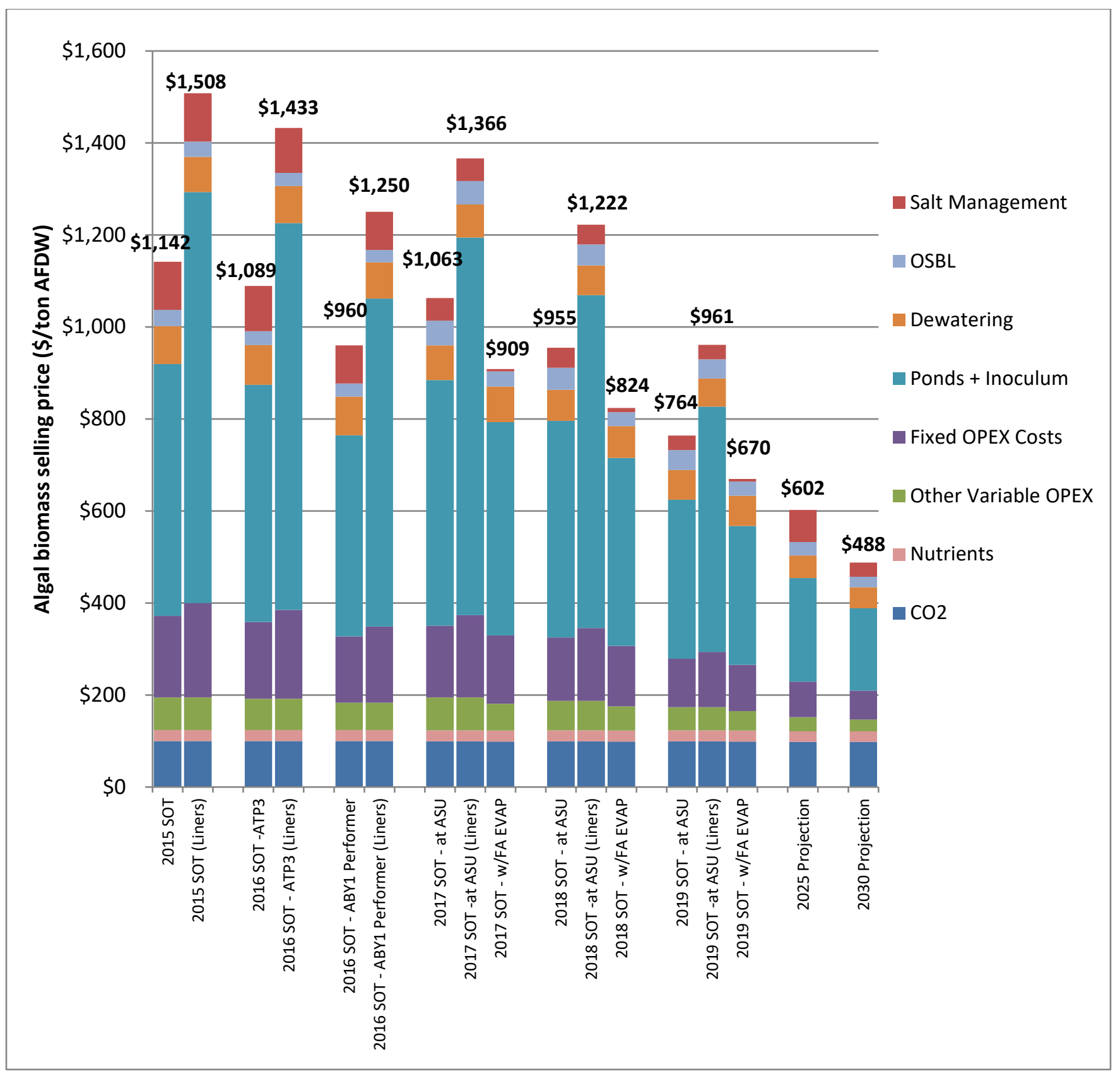

Figure 2. Biomass production MBSP results and cost breakdowns by major contributions for 2019 SOT, compared against 2015-2018 SOTs and 2025/2030 projections for reference [3] (2016\$, all based on HCSD composition).

First two 2017-2019 SOT bars are based on ASU cultivation performance with ASU local evaporation rates; third bar is based on ASU cultivation performance with Florida Algae (FA) evaporation rates. 
Table 5. Technical Overview Table for Cost and Process Metrics Associated with Current and Back-Cast Algal Biomass SOT Cases, Compared alongside Future 2025-2030 Projections - FA Evaporation Basis (costs in 2016\$).

\begin{tabular}{|c|c|c|c|c|c|c|c|c|c|}
\hline $\begin{array}{l}\text { Processing Area } \\
\text { Cost Contributions \& } \\
\text { Key Technical } \\
\text { Parameters }\end{array}$ & Metric & $\begin{array}{l}2015 \\
\text { SOT }^{\text {a }}\end{array}$ & $\begin{array}{l}2016 \\
\text { SOT - } \\
\text { ATP }^{3} \text { a }\end{array}$ & $\begin{array}{l}2016- \\
\text { ABY1 a }\end{array}$ & $\begin{array}{c}2017 \\
\text { SOT (FA } \\
\text { Evap) }\end{array}$ & $\begin{array}{c}2018 \\
\text { SOT }(F A \\
\text { Evap) }\end{array}$ & $\begin{array}{c}2019 \\
\text { SOT (FA } \\
\text { Evap) }{ }^{\mathrm{a}, \mathrm{d}}\end{array}$ & $\begin{array}{c}2025 \\
\text { Projection }\end{array}$ & $\begin{array}{c}2030 \\
\text { Projection }\end{array}$ \\
\hline $\begin{array}{l}\text { Biomass Selling Price } \\
\text { (With Liners) }\end{array}$ & $\begin{array}{l}\text { \$/ton } \\
\text { AFDW }\end{array}$ & $\begin{array}{l}\$ 1142 \\
(\$ 1508)\end{array}$ & $\begin{array}{l}\$ 1089 \\
(\$ 1433)\end{array}$ & $\begin{array}{c}\$ 960 \\
(\$ 1250)\end{array}$ & $\begin{array}{c}\$ 909 \\
(\$ 1211)\end{array}$ & $\begin{array}{c}\$ 824 \\
(\$ 1090)\end{array}$ & $\begin{array}{l}\$ 670 \\
(\$ 866)\end{array}$ & $\$ 602$ & $\$ 488$ \\
\hline $\begin{array}{l}\text { Production Cost (With } \\
\text { Liners) }\end{array}$ & $\begin{array}{l}\text { \$/ton } \\
\text { AFDW }\end{array}$ & $\begin{array}{c}\$ 999 \\
(\$ 1365)\end{array}$ & $\begin{array}{c}\$ 947 \\
(\$ 1291)\end{array}$ & $\begin{array}{c}\$ 824 \\
(\$ 1115)\end{array}$ & $\begin{array}{c}\$ 775 \\
(\$ 1078)\end{array}$ & $\begin{array}{l}\$ 704 \\
(\$ 970)\end{array}$ & $\begin{array}{l}\$ 556 \\
(\$ 752)\end{array}$ & $\$ 509$ & $\$ 400$ \\
\hline $\begin{array}{l}\text { Harvest/Dewatering } \\
\text { Cost }\end{array}$ & $\begin{array}{l}\text { \$/ton } \\
\text { AFDW }\end{array}$ & $\$ 105$ & $\$ 110$ & $\$ 107$ & $\$ 97$ & $\$ 87$ & $\$ 82$ & $\$ 62$ & $\$ 63$ \\
\hline $\begin{array}{l}\text { Other Cost (Facility } \\
\text { Circulation, Storage) }\end{array}$ & $\begin{array}{l}\text { \$/ton } \\
\text { AFDW }\end{array}$ & $\$ 38$ & $\$ 32$ & $\$ 28$ & $\$ 36$ & $\$ 33$ & $\$ 32$ & $\$ 32$ & $\$ 25$ \\
\hline $\begin{array}{l}\text { Net Biomass } \\
\text { Production Yielde }\end{array}$ & $\begin{array}{l}\text { Ton } \\
\text { AFDW/ } \\
\text { Acre-year }\end{array}$ & 12.4 & 13.2 & 15.6 & 15.0 & 17.0 & 23.1 & 29.9 & 37.2 \\
\hline $\begin{array}{l}\text { Cultivation Productivity } \\
\text { (Annual Average) }\end{array}$ & $\mathrm{g} / \mathrm{m}^{2} /$ day & 8.5 & 9.1 & 10.7 & 10.3 & 11.7 & 15.9 & 20 & 25 \\
\hline $\begin{array}{l}\text { Max Seasonal } \\
\text { Production Variability }\end{array}$ & $\begin{array}{l}\text { Max:Min } \\
\text { Productivity }\end{array}$ & $2.3: 1$ & $2.6: 1$ & $3.6: 1$ & $2.6: 1$ & $2.0: 1$ & $4.2: 1$ & $3: 1$ & $3: 1$ \\
\hline $\begin{array}{l}\text { Biomass Harvest } \\
\text { Concentration }\end{array}$ & g/L AFDW & 0.27 & 0.26 & $\sim 0.5$ & 0.43 & 0.51 & 0.49 & 0.5 & 0.5 \\
\hline $\begin{array}{l}\text { Total Farm Power } \\
\text { Demand }\end{array}$ & $\begin{array}{l}\mathrm{KWh} / \text { ton } \\
\text { AFDW }\end{array}$ & 860 & 831 & 739 & 717 & 647 & 529 & 395 & 334 \\
\hline
\end{tabular}

${ }^{\text {a }}$ Base case assumes $\mathrm{n}^{\text {th }}$-plant facility utilizing low-cost unlined ponds; alternative SOT scenarios consider fully lined ponds with resulting costs shown in parentheses

${ }^{b}$ FY17 values shown are for FA evaporation basis for consistency with prior FY15-16 SOTs and future projection cases. ASU evaporation basis values are as follows: Biomass selling price $=\$ 1063 /$ ton $(\$ 1366 /$ ton lined); production cost $=\$ 896 /$ ton $(\$ 1199 /$ ton lined); harvest $/$ dewatering cost $=\$ 93 /$ ton; other cost $=\$ 74 /$ ton .

${ }^{\mathrm{c}} \mathrm{FY} 18$ values shown are for FA evaporation basis for consistency with prior FY15-16 SOTs and future projection cases. ASU evaporation basis values are as follows: Biomass selling price $=\$ 955 /$ ton $(\$ 1222 /$ ton lined); production cost $=\$ 806 /$ ton $(\$ 1073 /$ ton lined); harvest $/$ dewatering cost $=\$ 84 /$ ton; other cost $=\$ 65 /$ ton .

${ }^{d}$ FY19 values shown are for FA evaporation basis for consistency with prior FY15-16 SOTs and future projection cases. ASU evaporation basis values are as follows: Biomass selling price $=\$ 764 /$ ton $(\$ 961 /$ ton lined); production cost $=\$ 629 /$ ton $(\$ 827 /$ ton lined); harvest $/$ dewatering cost $=\$ 79 /$ ton; other cost $=\$ 55 /$ ton .

e Net yield to downstream conversion, after blowdown/short-term storage losses

\section{Sustainability Metric Indicators}

In addition to the TEA results noted above, here we also report on associated sustainability "indicators" attributed to the algae farm SOT model. In keeping with recent BETO guidance for all formal life cycle assessment (LCA) sustainability metrics to be handled by Argonne National Laboratory to ensure no inconsistencies in such metrics versus NREL-calculated values (i.e., using GREET versus SimaPro), we avoid reporting on LCA parameters such as greenhouse gas emissions or fossil energy consumption in this report (but are currently working to provide the input/output inventories to partners at ANL). Instead, Table 6 summarizes key sustainability 
indicators as may be taken directly from the Aspen Plus process models. Namely, for the biomass production SOT this includes areal biomass yields, carbon efficiency from delivered $\mathrm{CO}_{2}$, facility power demand, and water consumption. On the latter parameter, net makeup water demands are listed, but because this SOT and all future projections are to be based on saline cultivation per recent BETO guidance, this does not count against formal consumptive water use which is based strictly on freshwater consumption (zero in the case of the algal biomass production models). The process input/output inventories furnished to ANL for subsequent LCA supply chain sustainability analysis (SCSA) are summarized in Appendix B.

Table 6. Sustainability Indicators for FY19 SOT Biomass Model

\begin{tabular}{|c|c|c|c|}
\hline \multirow[b]{2}{*}{ Parameter } & & \multicolumn{2}{|c|}{ FY19 SOT Evaporation Basis } \\
\hline & & ASU Evap & FA Evap \\
\hline Net biomass yield to conversion & Ton/acre-yr AFDW a & 23.1 & 23.1 \\
\hline Carbon Efficiency to Biomass & $\%$ of delivered $\mathrm{CO}_{2}{ }^{\mathrm{b}}$ & $90 \%$ & $90 \%$ \\
\hline Electricity Import & kWh/Ton AFDW & 651 & 529 \\
\hline Natural Gas Import & MJ/Ton AFDW & NA & NA \\
\hline Water Consumption (SALINE ONLY) & gal/Ton AFDW c & 131,985 & 9,720 \\
\hline Water Consumption (SALINE ONLY) & $\mathrm{m}^{3} / \mathrm{day}^{\mathrm{c}}$ & 174,493 & 12,894 \\
\hline
\end{tabular}




\section{Concluding Remarks}

Based on incorporating experimentally observed performance metrics for algal cultivation as achieved under DISCOVR efforts into NREL's latest algal biomass production model (while leaving all other process and costing assumptions for non-cultivation operations unchanged relative to the 2016 biomass design case), the estimated base case SOT minimum biomass selling price is \$764/ton AFDW in 2016 for ASU site evaporation/blowdown rates, or $\mathbf{\$ 6 7 0 / t o n}$ for Florida Algae evaporation/blowdown rates. This represents the best available seasonal cultivation data attributed to ASU production of Desmodesmus, Monoraphidium, and Scenedesmus strains rotated seasonally (overlayed with NREL's HCSD biomass composition), assuming an $n^{\text {th }}$-plant model utilizing low-cost unlined ponds. Alternatively, a scenario employing fully lined ponds would translate to a considerably higher SOT biomass cost of $\$ 961 /$ ton and \$866/ton for the ASU and FA evaporation cases, respectively. The SOT MBSP value is tied primarily to ASU-demonstrated productivity rates, calculated at $15.9 \mathrm{~g} / \mathrm{m}^{2} /$ day AFDW as seasonal averages for the AzCATI site. This represents a $36 \%$ improvement in productivity over the FY18 SOT basis at $11.7 \mathrm{~g} / \mathrm{m}^{2} /$ day, leading to a roughly $20 \%$ reduction in SOT biomass cost. This is a substantial improvement, and likely attributed to continued focus on a hypothesis-driven approach to cultivation based on discussions and activities in consultation with the DISCOVR consortium, including the use of high-performing strains and different pond operational strategies (i.e. varying pond depths and incorporating fungicide to mitigate contamination during appropriate seasonal periods). Three out of four seasons were shown to result in higher productivities, with the largest single season improvement observed for summer cultivation (improved by 76\%) as the key enabling factor behind the substantial overall FY19 annual average productivity increase. While the cost of Fluazinam fungicide utilized experimentally in warm months was not explicitly included in this $n^{\text {th }}$-plant analysis, a preliminary sensitivity case estimates that its usage would incur a trivial penalty of roughly \$4/ton to overall MBSPs.

Given the significant logistical and cost challenges attributed to salt management and disposal in the case of saline cultivation, which are intensified in arid regions with high evaporation (as indicated by the MBSP differences above between ASU vs. FA evaporation), from strictly a practicality cost minimization standpoint this points to either (a) utilizing freshwater cultivation in those areas (which is also a challenge given limited freshwater resources in those same areas), or (b) siting commercial facilities in low-evaporation regions (e.g., U.S. Gulf Coast area). In light of the artificial cost impact incurred around evaporation/salt blowdown disposal which is otherwise irrelevant of scientific advancements, a more consistent basis for comparison to prior SOTs may be the ASU data overlaid with FA evaporation rates $(\$ 670 /$ ton MBSP $=19 \%$ reduction in MBSP relative to the FY18 SOT on this basis). In fact, because FA annual average productivity had originally been seen to be similar or marginally better than at ASU for both the FY15 and FY16 SOT datasets under $\mathrm{ATP}^{3}$, the MBSP may plausibly be expected to be even lower than the $\$ 670 /$ ton value if the FA site were still available. Moving forward, we will continue engaging with the DISCOVR project and PNNL's BAT team to support future SOT experimental planning, to be executed at least at the primary ASU testbed site (and potentially an additional site in Florida if one can be located), and to extrapolate the resulting cultivation data out to a consistent basis location and ideally across 30 years of weather data for that location. 
As part of future SOT efforts, it is hoped that cultivation trials can credibly demonstrate substantial improvements in both productivity as well as compositional quality, in moving towards 2030 design case targets. On the latter metric, in order to improve compositional quality particularly towards higher-carbohydrate/lower-protein biomass, Nannochloropsis has been eliminated from seasonal strain rotations in the FY19 SOT, recognizing it will never achieve a suitable composition for CAP conversion particularly around carbohydrates. However, given near-term BETO goals around out-year productivity targets, this will likely be the higher-priority focus area over coming years. Additionally, other gaps that could be better addressed in future SOT iterations include tracking (and ultimately improving on) $\mathrm{CO}_{2}$ utilization efficiency, TEA implications of cultivation dynamics around batch versus semi-continuous harvesting, cost tradeoffs between contamination mitigation measures versus crash frequency or growth rate penalties, and experimental demonstrations for dewatering efficacy or at least propensity for a strain to settle. Likewise, a more detailed TEA approach to quantifying economic implications for seasonal strain rotation to weigh penalties versus benefits relative to use of a single strain year-round would be useful moving forward. Such details as these are planned to be incorporated into a new pre- $n^{\text {th }}$-plant "operational baseline" metric under the new TEA subtask of the DISCOVR consortium beginning in FY20.

Consistent with prior SOT conclusions, we reiterate that improving cultivation performance (yields/compositions) and controlling cultivation costs will be key to achieving economically viable algal biofuels for any conversion pathway option. On the cost control side, this would call for eventually demonstrating the viable use of large-scale unlined growth ponds on the order of 10 acres in size [3], or potentially pursuing low-cost PBR/pond hybrid systems as recently published in literature [8,9]. Additionally, algal wastewater treatment may provide alternative cost benefits including reduced nutrient costs and water treatment credits [21]; this point has been recently been reinforced through discussions with wastewater treatment technology providers in industry who are looking to scale-up algal wastewater treatment in the near-term, as well as through internal NREL TEA modeling to quantify economic incentives for algal water treatment scenarios, albeit at more limited national scalability for commodity biomass/biofuel production potential. 


\section{References}

NREL milestone reports cited below cannot be accessed outside of NREL and DOE. Readers may contact the authors of those reports to determine if this information has been made public since publication of this report.

1. AspenPlus2007 7.2. Cambridge MA. http://www.aspentech.com.

2. Davis, R., C. Kinchin, J. Markham, E. C. D. Tan, L. M. L. Laurens, D. Sexton, D. Knorr, P. Schoen, and J. Lukas. Process Design and Economics for the Conversion of Algal Biomass to Biofuels: Algal Biomass Fractionation to Lipid-and Carbohydrate-Derived Fuel Products. NREL/TP-5100-62368. Golden, CO: National Renewable Energy Laboratory, 2014. Available: https://www.nrel.gov/docs/fy14osti/62368.pdf.

3. Davis, R., J. Markham, C. Kinchin, N. Grundl, E. C. D. Tan, and D. Humbird. Process Design and Economics for the Production of Algal Biomass: Algal Biomass Production in Open Pond Systems and Processing Through Dewatering for Downstream Conversion. NREL/TP-510064772. Golden, CO: National Renewable Energy Laboratory, 2016. Available:

http://www.nrel.gov/docs/fy16osti/64772.pdf.

4. DOE. Bioenergy Technologies Office Multi Year Program Plan-March 2016. Washington, D.C.: Bioenergy Technologies Office, 2016. Available:

http://energy.gov/sites/prod/files/2016/03/f30/mypp beto march2016 2.pdf.

5. Kinchin, C., J. Markham, E. Knoshaug, and R. Davis. Algae Testbed Public Private Partnership (ATP3): Report on TEA modeling with complete UFS data set. NREL milestone report, 2015.

6. Knoshaug, E., L. Laurens, C. Kinchin, and R. Davis. Use of Cultivation Data from the Algae Testbed Public Private Partnership as Utilized in NREL's Algae State of Technology Assessments. NREL/TP-5100-67289. Golden CO: National Renewable Energy Laboratory, 2016. Available: http://www.nrel.gov/docs/fy17osti/67289.pdf.

7. McGowen, J., E. P. Knoshaug, L. M. L. Laurens, T. A. Dempster, P. T. Pienkos, E. Wolfrum, and V. L. Harmon. "The Algae Testbed Public-Private Partnership (ATP 3) framework;

establishment of a national network of testbed sites to support sustainable algae production." Algal Research, 25, 2017; 168-177. Available: https://doi.org/10.1016/j.algal.2017.05.017.

8. Beal, C. M., L. N. Gerber, D. L. Sills, M. E. Huntley, S. C. Machesky, M. J. Walsh, J. W. Tester, I. Archibald, J. Granados, and C. H. Greene. "Algal biofuel production for fuels and feed in a 100-ha facility: A comprehensive techno-economic analysis and life cycle assessment." Algal Research, 2015. Available: https://doi.org/10.1016/j.algal.2015.04.017.

9. Huntley, M. E., Z. I. Johnson, S. L. Brown, D. L. Sills, L. Gerber, I. Archibald, S. C. Machesky, J. Granados, C. Beal, and C. H. Greene. "Demonstrated large-scale production of marine microalgae for fuels and feed." Algal Research, 10, 2015; 249-265. Available:

https://doi.org/10.1016/j.algal.2015.04.016.

10. White, R. L., and R. A. Ryan. "Long-Term Cultivation of Algae in Open-Raceway Ponds: Lessons from the Field." Industrial Biotechnology, 11(4), 2015; 213-220. Available: https://doi.org/10.1089/ind.2015.0006. 
11. Hazlebeck, D. "Development of Algae Biomass Yield Improvements in an Integrated Process Phase I." Presented at U.S. Department of Energy (DOE) Bioenergy Technologies Office (BETO) 2017 Project Peer Review, March 7, 2017, Denver, CO. Available:

https://www.energy.gov/sites/prod/files/2017/05/f34/algae hazlebeck_135250.pdf

12. Davis, R., J. Markham, N. Grundl, and C. Kinchin. Path to $\$ 3 / G G E$. NREL milestone report, 2016.

13. Davis, R., D. Fishman, E. D. Frank, M. S. Wigmosta, A. Aden, A. M. Coleman, P. T. Pienkos, R. J. Skaggs, E. R. Venteris, and M. Q. Wang. Renewable Diesel from Algal Lipids: An Integrated Baseline for Cost, Emissions, and Resource Potential from a Harmonized Model. ANL/ESD/12-4. Argonne, IL: Argonne National Laboratory; NREL/TP-5100-67289. Golden CO: National Renewable Energy Laboratory; PNNL-21437. Richland, WA: Pacific Northwest National Laboratory, 2012. Available: http:/www.nrel.gov/docs/fy12osti/55431.pdf.

14. Davis, R. E., D. B. Fishman, E. D. Frank, M. C. Johnson, S. B. Jones, C. M. Kinchin, R. L. Skaggs, E. R. Venteris, and M. S. Wigmosta. "Integrated evaluation of cost, emissions, and resource potential for algal biofuels at the national scale." Environmental Science \& Technology, 48(10), 2014; 6035-6042. Available: https://doi.org/10.1021/es4055719.

15. Davis, R., and J. Clippinger. 2018 Algae Platform State of Technology Update. NREL milestone report, 2018.

16. Negewo, B. D. Renewable energy desalination: an emerging solution to close the water gap in the Middle East and North Africa ed: World Bank Publications, 2012. Available:

http://documents.worldbank.org/curated/en/443161468275091537/Renewable-energy-desalinationan-emerging-solution-to-close-the-water-gap-in-the-Middle-East-and-North-Africa.

17. McCurdy, R. "Underground injection wells for produced water disposal." Presented at Proceedings of the Technical Workshops for the Hydraulic Fracturing Study: Water Resources Management. EPA, 2011. Available:

https://www.epa.gov/sites/production/files/documents/21_McCurdy__UIC_Disposal_508.pdf.

18. Burnett, D. "Desalinating brine from oil and gas operations in Texas." Southwest Hydrology, Nov.-Dec, 2005. Available: http://www.swhydro.arizona.edu/archive/V4 N6/feature4.pdf.

19. Tultz, A., and K. Bell. "PA prefers recycling brine, Ohio favors injection." The News OutletPartners in Engaging Journalism.

20. "Options to Help Oklahoma Alleviate Its Emerging Oilfield Water Crisis." Newsfeed, edited by Baker \& Hostetler LLP, 2016. Available:

https://www.lexology.com/library/detail.aspx?g=01ea6d64-17e5-4c50-9308-2def24ca38f5.

21. Lundquist, T. J., I. C. Woertz, N. W. T. Quinn, and J. R. Benemann. A Realistic Technology and Engineering Assessment of Algae Biofuel Production. 2010. Available:

https://digitalcommons.calpoly.edu/cgi/viewcontent.cgi?referer=https://www.bing.com/\&httpsredir= $\underline{1 \& \text { article }=1189 \& \text { context }=\text { cenv fac. }}$.

22. Davis, R., M. Wiatrowski, and C. Kinchin. Deliver conceptual basis for updated CAP designfirst draft for review. NREL milestone report, 2019. 


\title{
Appendix A. TEA Summary Sheet for Base Case Biomass Cultivation SOT Benchmark Model (FA and ASU evaporation MBSP scenarios, 2016 dollars)
}

\author{
Algal Biomass Production Process Engineering Analysis \\ 2019 SOT with FA Evaporation Rates \\ All Values in $2016 \$$ \\ MBSP (Minimum Biomass Selling Price): \\ Contributions: $\quad \mathrm{CO} 2$ and Nutrients \\ Cultivation \\ Other Production \\ Total Biomass Production (AFDW Basis) \\ Total Biomass Yield (AFDW Basis) \\ Internal Rate of Return (After-Tax) \\ Equity Percent of Total Investment

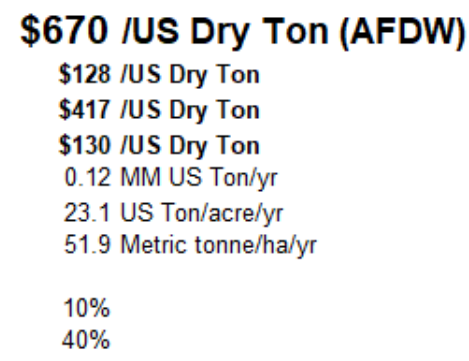

\begin{tabular}{lr}
\multicolumn{2}{c}{ Capital Costs } \\
\hline Production ponds (AVERAGE of 10-acre Cases) \\
Inoculum Ponds \\
CO2 Delivery & $\$ 151,000,000$ \\
Makeup Water Delivery + On-Site Circulation & $\$ 1,400,000$ \\
Dewatering & $\$ 8,900,000$ \\
Storage & $\$ 36,300,000$ \\
& $\$ 3,300,000$ \\
\hline Total Installed Equipment Cost & $\$ 219,700,000$ \\
& \\
Added Direct + Indirect Costs & $\$ 141,900,000$ \\
$\quad$ (\% of TCl) & $39 \%$ \\
Total Capital Investment (TCl) & $\$ 361,600,000$ \\
& \\
Installed Equipment Cost/Annual US dry ton biomass & $\$ 1,900$ \\
Total Capital Investment/Annual US dry ton biomass & $\$ 3,126$ \\
Loan Rate & $8.0 \%$ \\
Term (years) & 10 \\
Capital Charge Factor (Computed) & 0.127
\end{tabular}

\begin{tabular}{lr}
\multicolumn{2}{c}{ Manufacturing Costs (\$/US Ton AFDW Biomass product) } \\
\hline CO2 & $\$ 98.84$ \\
Nutrients & $\$ 23.67$ \\
Salt Disposal & $\$ 5.63$ \\
Power & $\$ 36.08$ \\
Other Operating Costs & $\$ 6.23$ \\
Fixed Costs & $\$ 100.60$ \\
Capital Depreciation & $\$ 92.51$ \\
Average Income Tax & $\$ 32.00$ \\
Average Return on Investment & $\$ 273.94$ \\
& \\
& \\
\hline$\quad$ Manufacturing Costs (\$/yr) & \\
\hline CO2 & $\$ 11,400,000$ \\
Ammonia & $\$ 2,000,000$ \\
Diammonium Phosphate & $\$ 800,000$ \\
Power & $\$ 4,200,000$ \\
Chilled Water Utility & $\$ 700,000$ \\
Fixed Costs & $\$ 11,600,000$ \\
Capital Depreciation & $\$ 10,700,000$ \\
Average Income Tax & $\$ 3,700,000$ \\
Average Return on Investment & $\$ 31,700,000$
\end{tabular}




\section{Algal Biomass Production Process Engineering Analysis}

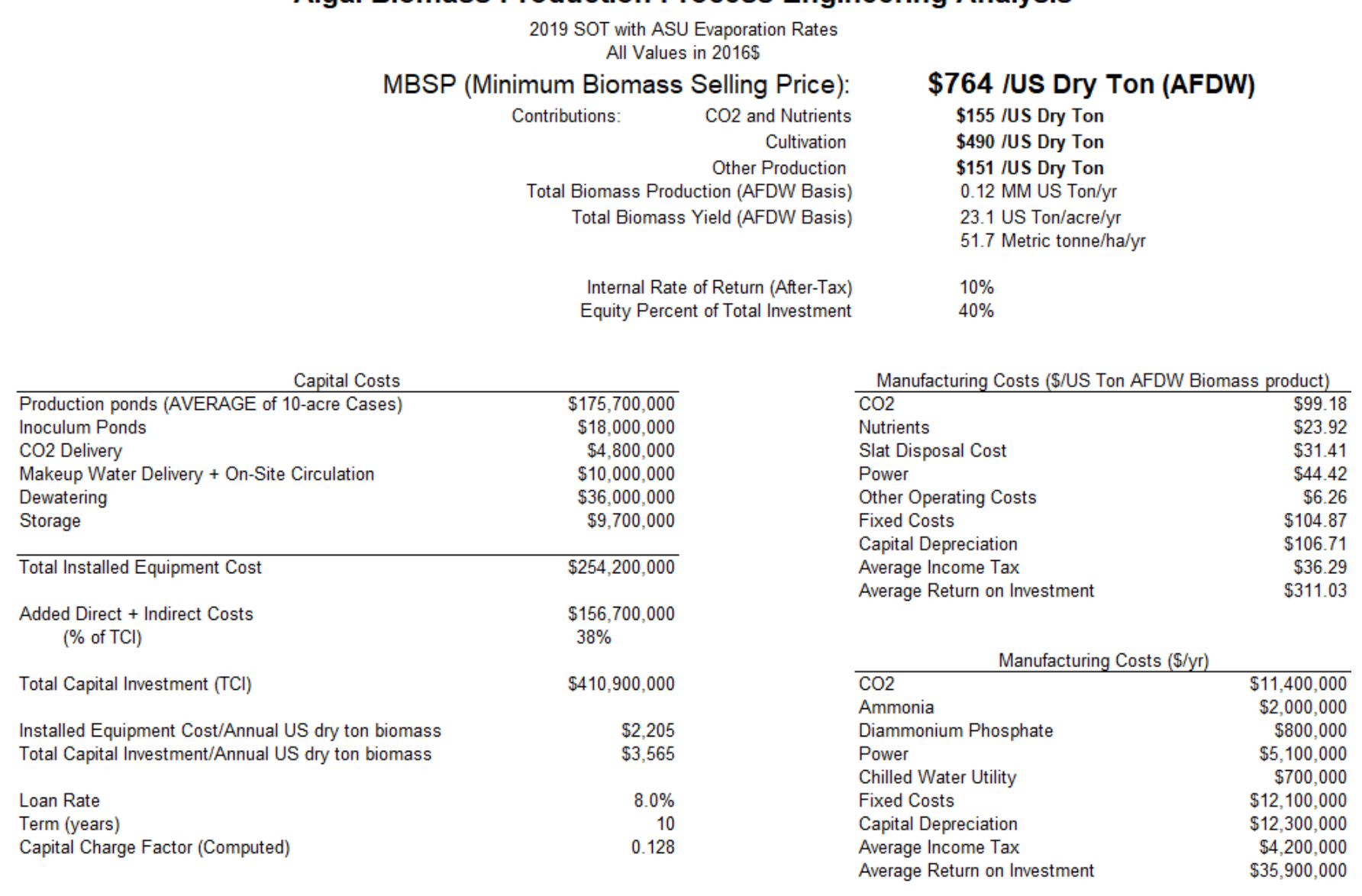




\section{Appendix B. Life-Cycle Inventory (LCl) for 2019 SOT Algae Farm Model}

Table B-1. SOT Front-End Input and Output Data for the Modeled ASU Production Facility (10-acre average base case). (Note: Daily rates shown below are based on annual averages over all modeled seasons based on 24-hour day.)

\begin{tabular}{|c|c|c|}
\hline Products, kg/hr & $\begin{array}{l}\text { Annual Average Rates } \\
\text { FA Evap }\end{array}$ & $\begin{array}{l}\text { Annual Average Rates } \\
\text { ASU Evap }\end{array}$ \\
\hline Algal biomass (AFDW) ${ }^{a}$ & 13,246 & 13,201 \\
\hline Algal biomass (total including ash) a & 13,575 & 13,529 \\
\hline \multicolumn{3}{|l|}{ Resource Consumption, $\mathrm{kg} / \mathrm{hr}$} \\
\hline $\mathrm{CO}_{2}$ (counted as biogenic) & 29,441 & 29,441 \\
\hline Ammonia & 265 & 267 \\
\hline DAP & 128 & 129 \\
\hline Total process water input (SALINE) ${ }^{\mathrm{b}}$ & 537,257 & $7,270,538$ \\
\hline Electricity demand, kW & 7,566 & 9,283 \\
\hline \multicolumn{3}{|l|}{ Output Streams, kg/hr } \\
\hline Water in biomass product stream & 53,519 & 53,336 \\
\hline Water lost to blowdown & 91,054 & $1,011,421$ \\
\hline Algae lost in blowdown & 5 & 51 \\
\hline \multicolumn{3}{|l|}{ Air Emissions, kg/hr } \\
\hline Water lost to evaporation & 379,318 & $6,140,575$ \\
\hline $\begin{array}{l}\mathrm{CO}_{2} \text { outgassing from ponds (counted as } \\
\text { biogenic) }\end{array}$ & 2,944 & 2,944 \\
\hline $\mathrm{O}_{2}$ to atmosphere & 22,839 & 22,839 \\
\hline
\end{tabular}

a Total after $1 \%$ algae loss for storage.

b Total water input, including the amount contained in the biomass product stream sent to conversion (in many cases, a large fraction of this water is ultimately recycled back to ponds from downstream conversion steps); all makeup water is saline. 